\title{
The content of nitrogen compounds in the Wel river in the light of the Nitrates Directive
}

\author{
Maciej Operacz, Andrzej Kentzer, Lukasz Nowaczyk \\ Department of Hydrobiology, Institute, of Ecology and Environmental Protection, \\ Nicolaus Copernicus University, Gagarina 9, 87-100 Torun, Poland \\ e-mail: operacz@umk.pl
}

\begin{abstract}
In this paper, the results of the research are presented on the content and transformation of nitrogen compounds in the Wel River (the largest tributary of the Drwęca River). The catchment area of the studied river is predominantly agriculturally developed. Along the river course, 6 sample collection sites were selected, situated in places with different land development of the drainage basin. The average concentration of total nitrogen in the water of the Wel River amounted to $1.807 \mathrm{mg} / \mathrm{dm}^{3}$, mineral nitrogen -0.557 $\mathrm{mg} / \mathrm{dm}^{3}$ and organic nitrogen $-1.250 \mathrm{mg} / \mathrm{dm}^{3}$. The organic form of nitrogen dominated at all sites (the average content for the whole river amounted to $69 \%$ ). Nitrate nitrogen dominated in the pool of mineral nitrogen. The lowest concentrations of nitrates were being recorded at lakeland sites, whereas the highest - at two terminal sites situated within the lower reaches of the river, where the drainage basin has a typically agricultural character.
\end{abstract}

Key words: Nitrates Directive, Wel River, flow-through lakes, agricultural catchment.

\section{Introduction}

The content of nitrogen is one of the main indicators used for the assessment of the quality of surface waters, whereas the concentration of mineral nitrogen compounds (ammonium and nitrate ions) is an important criterion for determining the usefulness of water for consumption (Hatfield $\&$ Follett 2008). Nitrogen gets into the surface waters from the drainage basin due to mineralization of organic matter, together with wastewaters, with atmospheric precipitation, from the atmosphere (diffusion), and also as a result of fixation of atmospheric nitrogen by microorganisms, such as blue-green algae and bacteria. a number of studies and researches revealed, however, that agriculture is the main source of contamination of surface waters with nitrogen compounds. Fertilizer components unused in the agriculture can penetrate into underground and surface waters, causing their contamination. This type of pollution is described as nonpoint source pollution and may affect up to $70 \%$ of the agriculturally exploited area of the country (Sapek 1996).

In the surface waters, nitrogen occurs in two forms: organic and mineral one. Mineral forms of nitrogen are readily soluble and usually get into the surface waters from the drainage basin (mainly nonpoint sources). The organic form of nitrogen usually inflows together with soil particles (erosion) and untreated wastewaters. During the growing season, usually the organic form dominates in the surface waters, while during the winter season - the mineral form. Whereas, in the conditions of good oxygenation, nitrates have the main contribution in the mineral form (Kajak 1998). As an important biogenic element, it significantly influences the processes of eutrophication taking place in water bodies. The dynamics of nitrogen compounds is very complex due to the fact that this element occurs in many forms (Dodds 2002).

Due to a significant increase in the contamination of surface waters with nitrogen compounds, recorded in the last decades, in 1991 the European Union introduced the 
so-called Nitrates Directive, the objective of which is to protect the surface waters against nitrogen pollutants from sources connected with agriculture. The Directive obliges the Member States of the European Union to perform the following actions:

- monitoring of the content of nitrates in the underground and surface waters;

- institution of voluntary codes of good agricultural practices;

- designation of areas particularly vulnerable to contamination of waters with nitrates;

- defining obligatory principles for the management of fertilizers and principles of agricultural science within the zones of particular sensitivity.

\section{Research methods}

Researches related to transformation of nitrogen compounds in the Wel River were conducted at monthly intervals from March to December 2008. Water samples were collected at six sites distributed along the entire length of the river, from its source to the mouth (Fig. 1). The Wel River is the largest tributary of the Drwęca River (a drinking water source for Toruń) with the length of ca. $110 \mathrm{~km}$ and the catchment area of ca. $800 \mathrm{~km}^{2}$. The average flow within the estuary section is ca. $5 \mathrm{~m}^{3} / \mathrm{s}$ (Główczyński et al. 2010). The catchment area of the Wel River is an area of outstanding nature and landscape values. Along a considerable length, the river flows through the Wel Landscape Park, which was created in order to protect the river.

Concentrations of mineral forms of nitrogen (nitrate nitrogen $\mathrm{N}-\mathrm{NO}_{3}$ and ammonia nitrogen $\mathrm{N}-\mathrm{NH}_{4}$ ) were determined in the collected water, using the standard methods of hydrochemical analysis (Hermanowicz et al. 1999). Organic nitrogen was determined with the Kjeldahl method. Concentrations of mineral nitrogen were obtained from calculations according to the formula:

$$
\mathrm{N}_{\text {min. }}=\mathrm{N}-\mathrm{NO}_{3}+\mathrm{N}-\mathrm{NH}_{4}
$$

Concentrations of organic nitrogen were calculated according to the formula:

$$
\mathrm{N}_{\text {org. }}=\mathrm{N}_{\mathrm{k} .}-\mathrm{N}-\mathrm{NH}_{4}
$$

Concentration of total nitrogen was calculated according to the formula:

$$
\mathrm{N}_{\text {tot. }}=\mathrm{N}_{\text {min. }}+\mathrm{N}_{\text {org. }}
$$

\section{Results and discussion}

The average value of the total nitrogen concentration for the Wel River along its entire length amounted to 1.807 $\mathrm{mg} / \mathrm{dm}^{3}$ during the research period (Fig. 2, 3). It enables to classify the waters of the studied river within purity class I. The average value at particular sites ranged from
$1.573 \mathrm{mg} / \mathrm{dm}^{3}$ at the site Szczupliny to $2.075 \mathrm{mg} / \mathrm{dm}^{3}$ at the site Koszelewki. At all sites (Fig. 3), organic nitrogen constituted the highest percentage of $\mathrm{N}_{\text {tot. }}$ (particularly Dąbrówno and Koszelewki, located downstream of flowthrough (open) lakes, $85 \%$ and $80 \%$, respectively). At the terminal, estuary site (Bratian), proportions of organic and mineral nitrogen in the total load of nitrogen were similar $\left(\mathrm{N}_{\text {org. }} 55 \%, \mathrm{~N}_{\text {min. }} 45 \%\right)$.

During the whole study period, considerable variability in the concentrations of total nitrogen in the Wel River was observed. At the first three sites, the concentration of total nitrogen basically has not been changing. Only the percentage contribution of mineral and organic forms has been changing. Transport of nitrogen is disturbed by the presence of open lakes. It is obvious that open lakes are the place of intensive nitrogen transformation. In the water flowing out of the lakes, a considerable increase was recorded in the content of organic nitrogen contained in the suspended matter and in planktonic organisms. Organic nitrogen was a dominant form in the total nitrogen.

This confirms the results obtained by Gołdyn (2000). The Cybina River after flowing through Lake Swarzędz contained much higher amounts of total nitrogen. This kind of situation, however, was taking place only in the summer months, during which the primary production proceeds on a larger scale as compared to winter months. Whereas Hillbricht-Ilkowska and Kostrzewska-Szlakowska (1996) did not find any statistically significant differences between lakes and the Krutynia River regarding the retention of total nitrogen. Also, it was not possible to describe explicitly the transport of nitrogen in the Babant River. The accumulation of this element was recorded in both studied lakes (Kufel 1996). Three open lakes of the headwater catchment of the Radunia River (Nowiński \& Lange 2004) were undoubtedly of depositional significance for nitrogen. Lake Stężyckie, located at the highest altitude in the cascade system, functioned as a ,sorptive complex" in relation to the remaining reservoirs, located at the lower altitude. The content of total nitrogen was decreasing as the water flows through three lakes located one after the other, from the value of $3.5 \mathrm{mg} / \mathrm{dm}^{3}$, through $1.0 \mathrm{mg} / \mathrm{dm}^{3}$, up to the value of $0.2 \mathrm{mg} / \mathrm{dm}^{3}$ in the lake situated at the lowest altitude. Different results, from these presented in this paper, were obtained by Lossow et al. (2006). They studied three open lakes, which were characterized by positive retention for nitrogen: $40.5 \%, 11.1 \%$ and $23.8 \%$ respectively for particular lakes. The authors report that the main form of nitrogen (similarly like in the Wel River) was organic nitrogen. Most probably this dissimilarity results from different hydrological conditions of open lakes.

Average concentration of total nitrogen at the level of $1.41 \mathrm{mg} / \mathrm{dm}^{3}$ was obtained by Lossow et al. (2006), who investigated rivers of north-eastern Poland - Marózka and Łyna, similar to the Wel River. When investigating the Ba- 


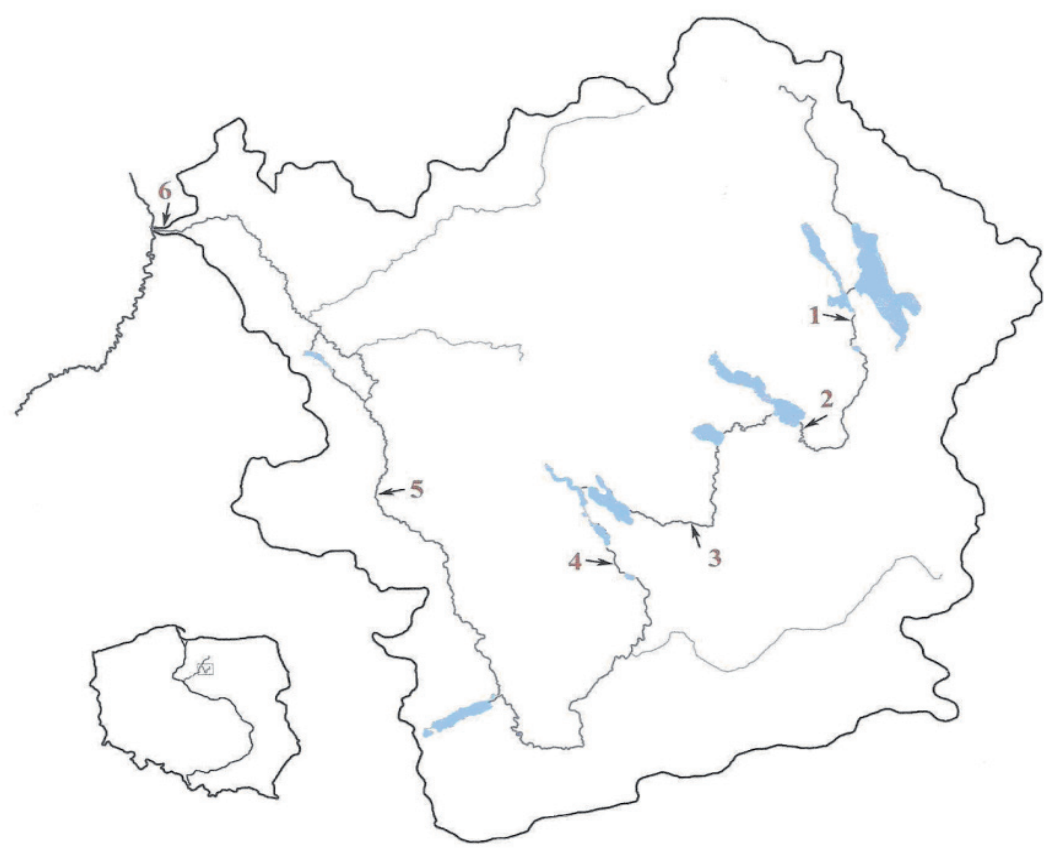

Figure 1. Fluvio-lacustrine system of the Wel River together with the drainage basin and sample collection sites: 1 - Dąbrówno, 2 Szczupliny, 3 - Grabacz, 4 - Koszelewki, 5 - Trzcin, 6 - Bratian

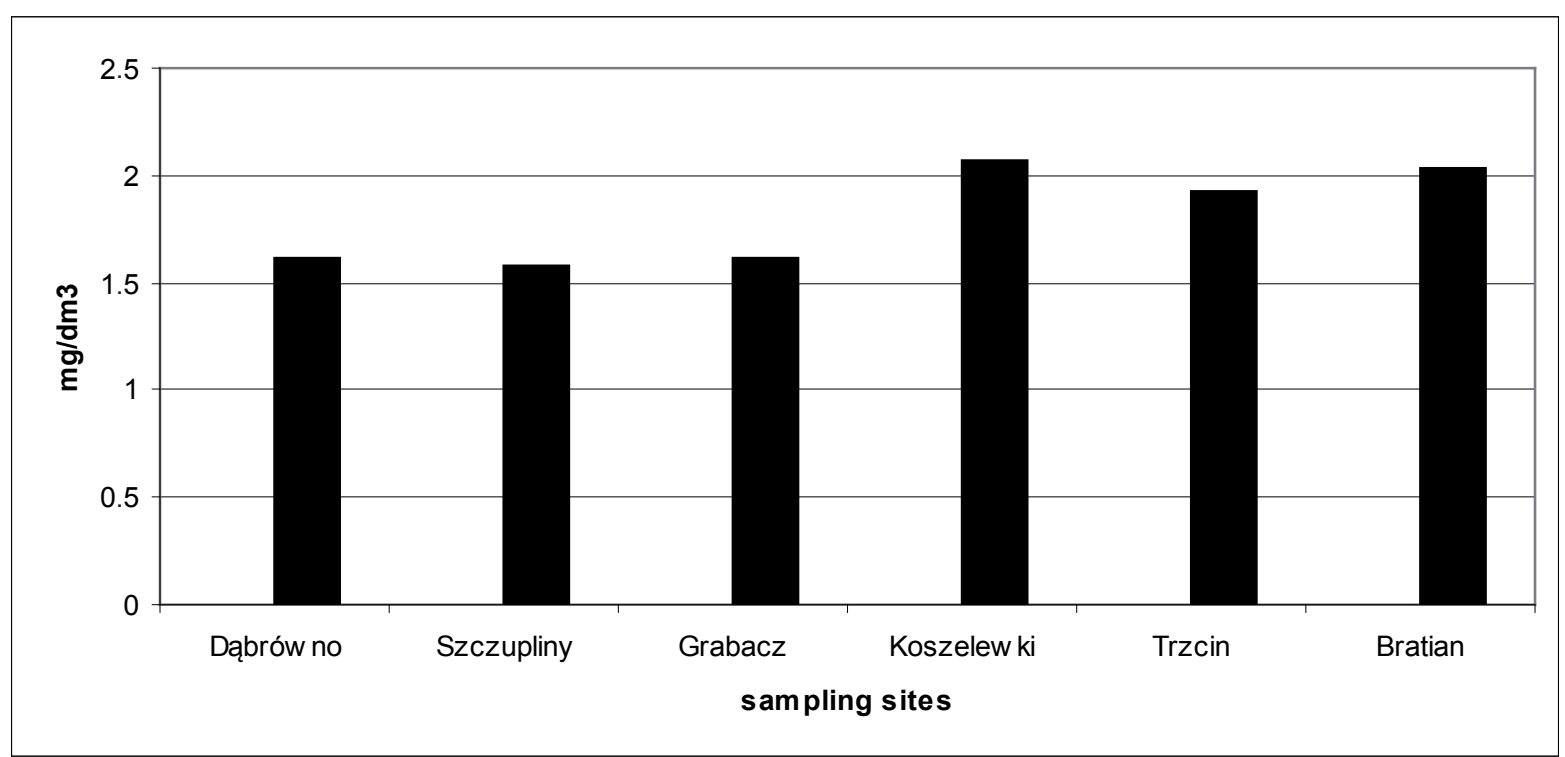

Figure 2. Average concentrations $\left[\mathrm{mg} / \mathrm{dm}^{3}\right]$ of total nitrogen at particular sites (March - December 2008) 


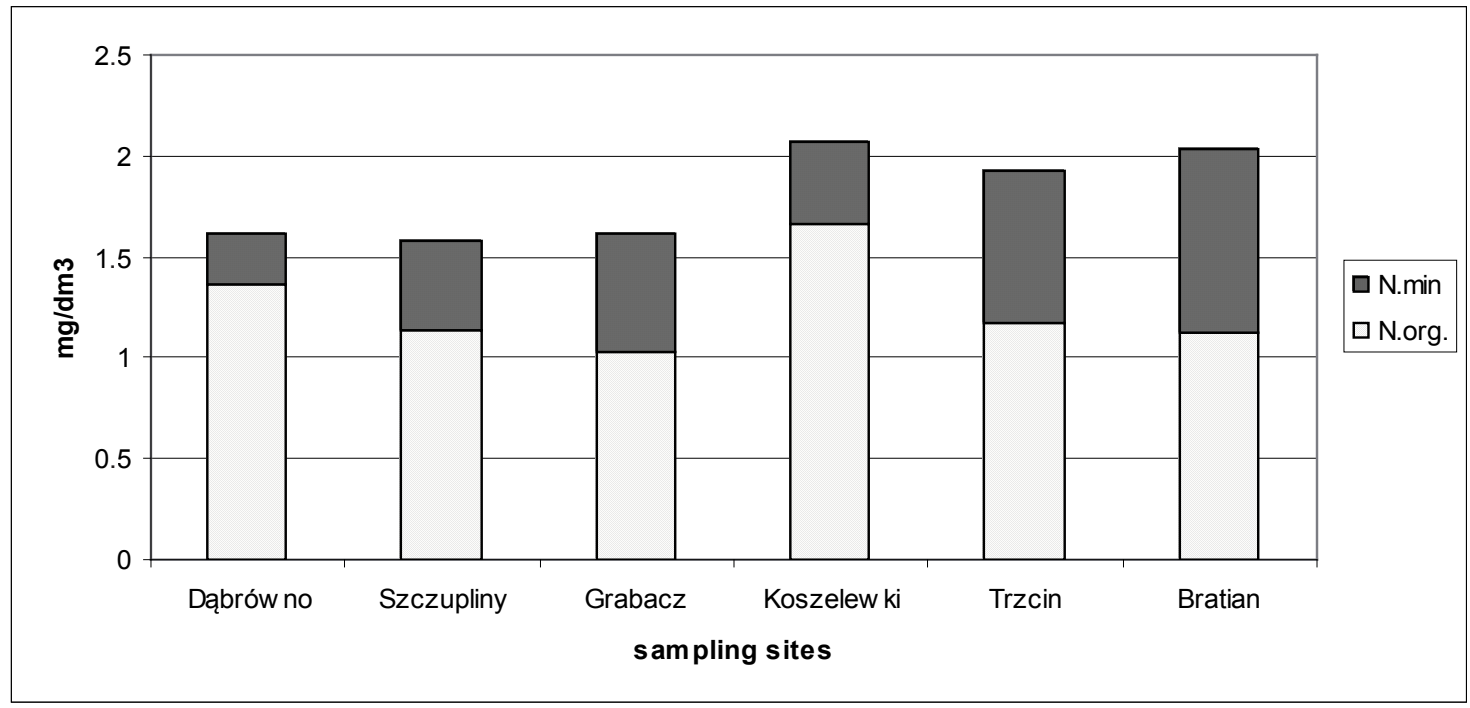

Figure 3. Contribution of mineral and organic nitrogen in $\mathrm{N}_{\text {tot. }}$ at particular sites (March-December 2008)

bant River (the Masurian Lakeland), Kufel (1996) obtained lower values of the total nitrogen. The average concentration of $\mathrm{N}_{\text {tot. }}$ in this river amounted to $1.11 \mathrm{mg} / \mathrm{dm}^{3}$. In the rivers of the Coastal Region, as well as in the Oder River and the Vistula River studied by Bogdanowicz (2004), the concentration of total nitrogen did not exceed the value of $5 \mathrm{mg} / \mathrm{dm}^{3}$. The lowest value he obtained for the Reda River was $1.9 \mathrm{mg} / \mathrm{dm}^{3}$, whereas the highest for the Rivers Ina and Oder $-4.15 \mathrm{mg} / \mathrm{dm}^{3}$. Whereas Granlund et al. (2005), who studied small Finnish rivers, draining mainly agricultural lands, recorded the average concentration of $\mathrm{N}_{\text {tot }}$, amounting to $2.96 \mathrm{mg} / \mathrm{dm}^{3}$.

The average value of mineral nitrogen for the Wel River along its whole length, during the research period, amounted to $0.557 \mathrm{mg} / \mathrm{dm}^{3}$ (Fig. 4, 5). The average value at particular sites ranged from $0.244 \mathrm{mg} / \mathrm{dm}^{3}$ at the site Dąbrówno (the source) to $0.911 \mathrm{mg} / \mathrm{dm}^{3}$ at the site Bratnia (the estuary) (Fig. 4). During the winter months, higher concentrations of mineral nitrogen were being recorded as compared to summer months. At all sites, the percentage contribution of the mineral form was lower as compared with the percentage contribution of the organic form (Fig. 3). At the terminal, estuary site (Bratian), the content of $\mathrm{N}_{\text {min. }}$ in $\mathrm{N}_{\text {tot. }}$ amounted to $45 \%$. At the first site (Dąbrówno), the content of $\mathrm{N}_{\text {min. }}$ in $\mathrm{N}_{\text {tot. }}$ was only $15 \%$.

At four, out of six, research sites, nitrate nitrogen was the dominant form of mineral nitrogen (Fig. 5). The average concentration of $\mathrm{N}-\mathrm{NO}_{3}$ during the research period amounted to $0.348 \mathrm{mg} / \mathrm{dm}^{3}$. The ammonia form dominated only at two middle sites (Grabacz and Koszelewki). From the obtained results, one can see a considerable increase in the concentration of nitrate nitrogen along the river course.
At the last site, the concentration of $\mathrm{N}-\mathrm{NO}_{3}$ was five times higher than at the first site. The increase in the content of this form of mineral nitrogen was brought about by the influence of a few factors. The waters receive the pollution from nearby areas with the surface run-off. Almost $70 \%$ of the catchment area of the Wel River is composed of agricultural lands, which are the main source of river water pollution with mineral forms of nitrogen. Tributaries, which disgorge into the river, intensively drain the agricultural lands, as well as carry the waters from nearby fish ponds. The Wel River receives also wastewaters from nearby treatment plants and industrial plants. The aforementioned factors, as well as the absence of open lakes in the lower reaches of the river bring about the fact that the contribution of mineral nitrogen increased along the river course. According to Bogdanowicz (2004), the high content of nitrates proves the significance of runoff from agricultural lands. Also Hatfield and Follett (2008), as well as Hillbricht-Ilkowska and Kostrzewska-Szlakowska (1996) report that waters flowing down the agricultural areas are characterized by high content of this nitrogen form. Slightly higher concentrations of nitrates during the winter months could be accounted for by the reduced primary production, and at the same time smaller demands for $\mathrm{N}-\mathrm{NO}_{3}$. Eighty five per cent of the rivers studied by Arheimer and Liden (2000) had significantly lower concentrations of nitrates during the summer months (May-August). Also the Vilaine River, studied by Moreau et al. (1998), was characterized by the highest concentrations of nitrates during the winter months and the lowest ones during the summer months. In lakeland rivers of NE Poland, the average concentration of $\mathrm{N}-\mathrm{NO}_{3}$ amounted to $0.293 \mathrm{mg} / \mathrm{dm}^{3}$ (Zieliński 


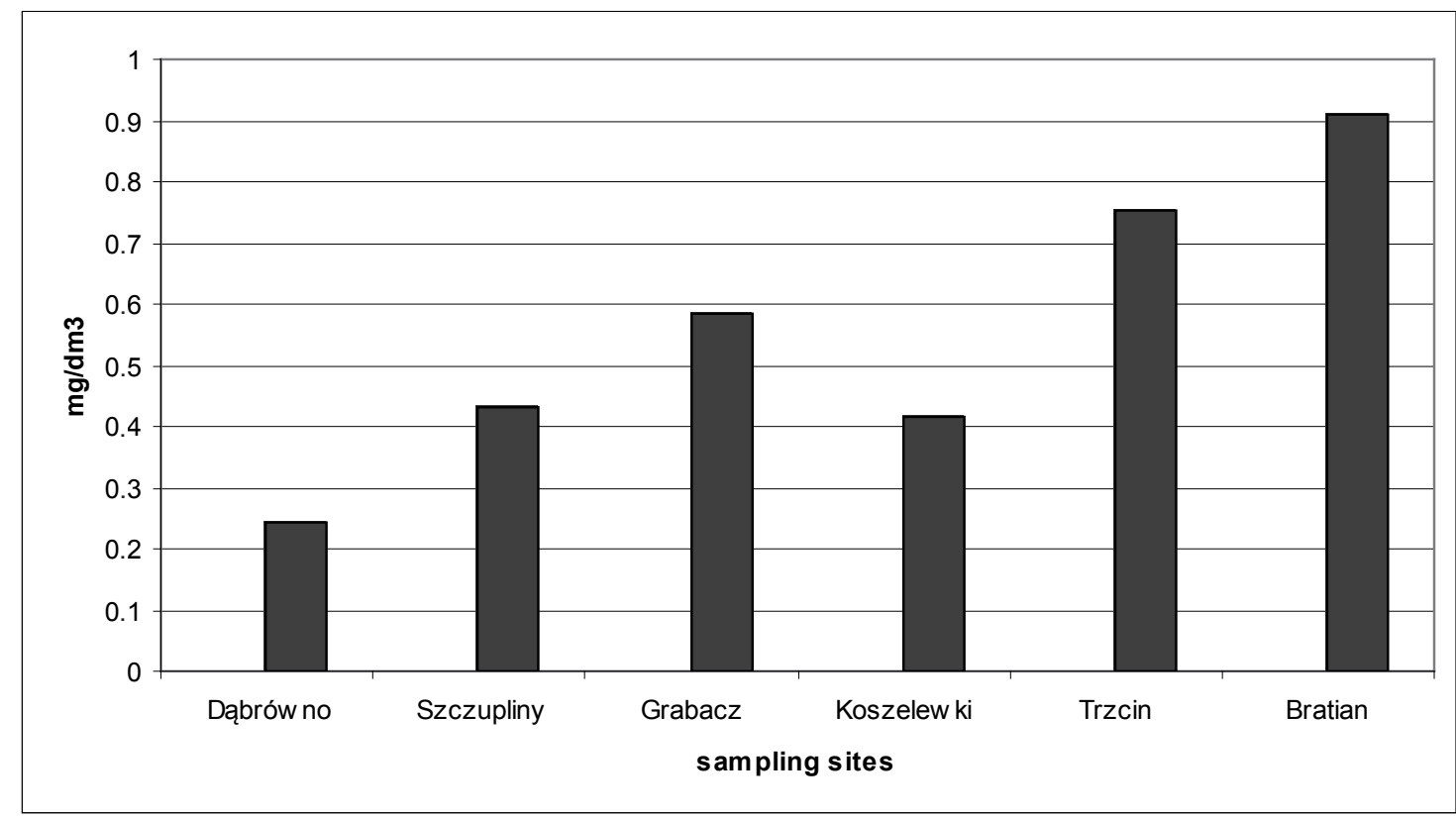

Figure 4. Average concentrations $\left[\mathrm{mg} / \mathrm{dm}^{3}\right]$ of mineral nitrogen at particular sites (March - December 2008)

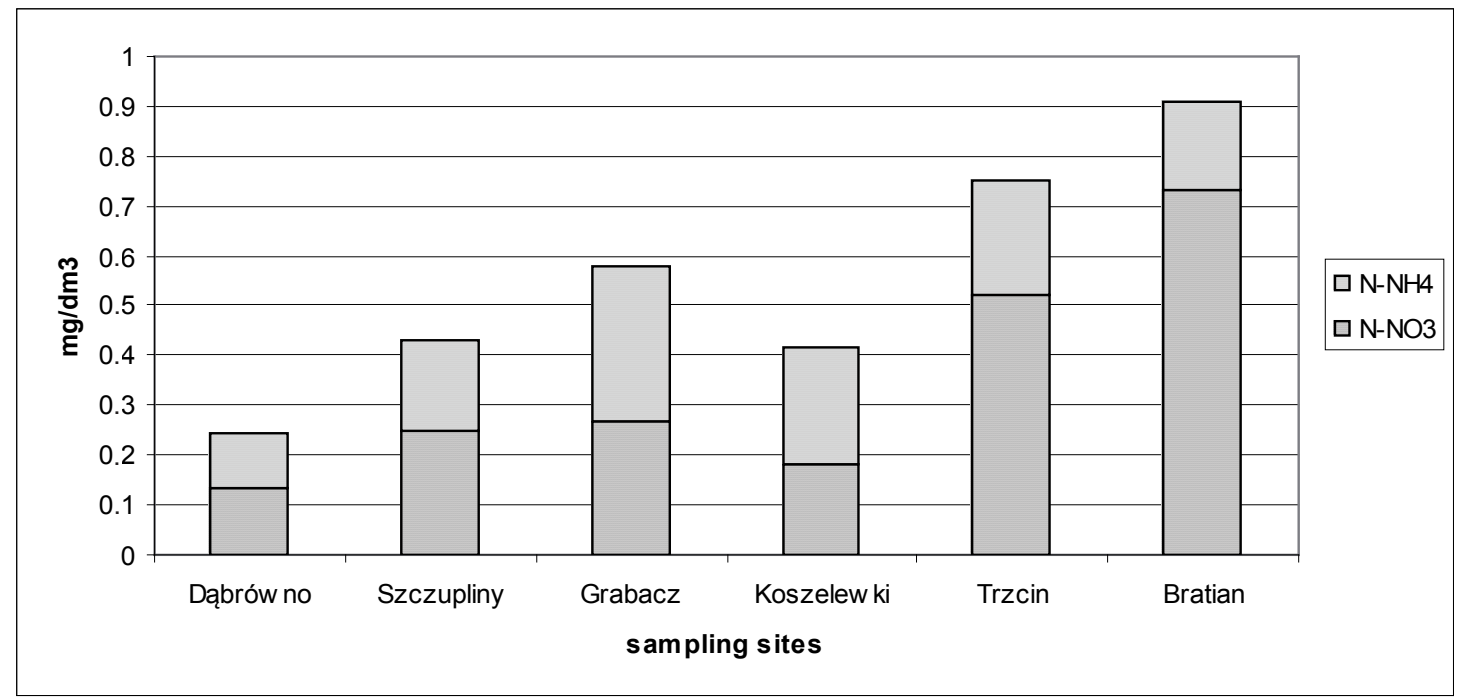

Figure 5. Contribution of ammonia nitrogen and nitrate nitrogen in the pool of mineral nitrogen at particular sites (March-December 2008)

2003). Whereas Bogdanowicz (2004), in his researches on the Vistula and Oder Rivers, as well as on rivers of the Coastal Region, obtained the average value of $1.535 \mathrm{mg}$ $\mathrm{N}-\mathrm{NO}_{3} / \mathrm{dm}^{3}$.

The lowest value of the nitrate nitrogen concentration in the presented studies was recorded at the sites downstream of the open lakes. This seems to be obvious due to intense assimilation of this form of nitrogen by phyto- plankton in the process of primary production. Gołdyn et al. (2005) recorded nearly $30 \%$ reduction in the concentration of $\mathrm{N}-\mathrm{NO}_{3}$ at sites downstream from the flow-through lakes. Furthermore, reduction of mineral nitrogen in lakes is determined by the process of denitrification. Kajak (1998) reports that denitrification is one of the main processes contributing to a decrease in the nitrogen content in water bodies. He estimates that up to $3 \mathrm{mg}$ nitrogen could 
be released from one litre of water per day in the denitrification process, and even up to $160 \mathrm{mg}$ nitrogen from $1 \mathrm{~m}^{2}$ sediments per day. This is reflected in the apparent drop of the mineral form of nitrogen at the sites downstream of the lakes. Researches by Pattinson et al. (1998) on the spatial diversity in the intensity of the denitrification process in sediments of the Swal River prove that the amount of released nitrogen increases along the river course from $20 \mu \mathrm{mol} \mathrm{N} / \mathrm{m}^{2} / \mathrm{h}$ within the headwater section to $659 \mu \mathrm{mol}$ $\mathrm{N} / \mathrm{m}^{2} / \mathrm{h}$ at the river mouth.

No nitrate-dilution effect has been observed along the river course. Allan (1998) reports that in rivers, in which the supply with this biogenic element is relatively constant, the increasing water volume will dilute a given substance. In the Wel River, where point sources of pollution are rare and nonpoint sources have a considerable contribution in water pollution of the river, the dilution effect has not been observed together with the increasing mileage of the river. a similar situation was observed by Lossow et al. (2006) who studied rivers similar to Wel, i.e. Marózka and Łyna. Concentrations of nitrates depend mainly on the water flow rate and they were increasing along the river course. Different results were obtained by Hillbricht-Ilkowska and Kostrzewska-Szlakowska (1996), who investigated the Krutynia River. In the Krutynia River, the concentration of the nitrate form was decreasing along the river course. The dilution effect was observed for nitrates received by the river together with its tributary within the initial reaches.

Only at two sites in the middle reaches of the river (Grabacz, Koszelewki), the ammonia form has a higher contribution in the pool of mineral nitrogen (Fig. 5), a considerable contribution of the ammonia ion most probably could be attributed to the influence exerted by processes of decomposition of organic matter flowing out of the open lakes (the process of ammonification). Additionally, the water outflowing from the lakes is usually leaner in oxygen, which leads to a decrease in the nitrification rate. Variable results were obtained by Gołdyn and Kowalczewska - Madura (2005) in their studies on the Cybina River. And thus, after the river flows out of Lake Iwno, a drop in the concentration of the ammonia form was recorded, from the value of $0.924 \mathrm{mg} / \mathrm{dm}^{3}$ to the value of $0.650 \mathrm{mg} / \mathrm{dm}^{3}$. Whereas along the further reaches of the river, after flowing out of Lake Swarzędz, an increase in the concentration of $\mathrm{N}-\mathrm{NH}_{4}$ was recorded, from the value of $0.711 \mathrm{mg} /$ $\mathrm{dm}^{3}$ up to the value of $0.902 \mathrm{mg} / \mathrm{dm}^{3}$. The highest average concentration of ammonia nitrogen was recorded at the site Grabacz. Much higher concentrations of ammonia nitrogen at this site were most probably connected with the presence of fish-breeding ponds in the neighbourhood. Fish ponds contribute locally with very high loads of ammonia due to high density of specimens in a relatively small water volume (low dilution) and their intense feeding (Kajak 1998). Lossow et al. (2006) observed an increase in the concentra- tion of ammonia nitrogen in the Marózka River, just below the places of water discharge from fish ponds. Similar observations were done by Raczyńska and Machuła (2006), and Orlik and Obroślak (2005). Within the lower reaches of the river, the concentration of the ammonia form decreased. This is probably connected with the process of nitrification, which in well oxygenated, rapid waters of the lower river reaches proceeds most intensively. The average concentration of ammonia nitrogen in 58 rivers of $\mathrm{NE}$ Poland amounted to $0.211 \mathrm{mg} / \mathrm{dm}^{3}$. The lowest average concentrations of ammonia nitrogen were recorded in the Szkwa River $\left(14.4 \mu \mathrm{g} / \mathrm{dm}^{3}\right)$, and the highest ones in the Leśna Prawa River (more than $2 \mathrm{mg} / \mathrm{dm}^{3}$ ) (Zieliński 2003). Bogdanowicz (2004), who studied the Vistula and Oder Rivers, as well as rivers of the Coastal Region recorded the average concentration of $\mathrm{N}-\mathrm{NH}_{4}$ equal to $0.247 \mathrm{mg} / \mathrm{dm}^{3}$ ).

\section{Conclusions}

1. According to guidelines of the Nitrates Directive (the maximum concentration for $\mathrm{N}_{\text {tot. }}>50 \mathrm{mg} / \mathrm{dm}^{3}$ and the maximum concentration for $\mathrm{N}-\mathrm{NO}_{3}>11.3 \mathrm{mg} / \mathrm{dm}^{3}$ ), the water of the studied river is characterized by very low, safe for the environment, content of nitrogen compounds.

2. The content of each of the analysed nitrogen forms (nitrate nitrogen, ammonia nitrogen, mineral, organic and total nitrogen) allow to classify the water of the Wel River from March to December 2008 along its entire length from the sources till the mouth - within the 1st category of surface water purity.

3. Nitrate nitrogen was the dominant form of mineral nitrogen. In the total nitrogen, the organic form predominates over the mineral one.

4. Flow-through (open) lakes have a significant influence on the transformation of nitrogen compounds in the studied river. At the sites located downstream of the open lakes, the content of mineral nitrogen (particularly the nitrate form) was evidently decreasing. Whereas, the content of organic nitrogen was increasing.

5. The lower reaches of the river were characterized by much higher concentrations of mineral nitrogen as compared with the upper and middle reaches.

\section{Acknowledgements}

The authors wish to extend their gratitude to Mr Krzysztof Główczyński, the Director of the Wel Landscape Park, for his comprehensive assistance during the field works. 


\section{References}

Allan J. D., 1998, Ekologia wód płynących [Stream ecology],Wydawnictwo Naukowe PWN, Warszawa.

Arheimer B. \& Liden R., 2000, Nitrogen and phosphorus concentrations from agricultural catchments - influence of spatial and temporal variables, Journal of Hydrology 227: 140-159.

Bogdanowicz R., 2004, Hydrologiczne uwarunkowania transportu wybranych związków azotu i fosforu Odrą i Wisłą oraz rzekami Przymorza do Bałtyku [Hydrological determinants of the transportation of some nitrogen and phosphorus compounds along the Oder and Vistula Rivers, as well as along the rivers of the Coastal Region into the Baltic Sea],Wydawnictwo Uniwersytetu Gdańskiego, Gdańsk.

Dodds W. K., 2002, Freshwater Ecology, Concepts and Environmental Applications, Academic Press, London.

Główczyński K., Ulanicka E., Mróz A., Szczepański M., Kosowicz M. \& Załuski T., 2010, Welski Park Krajobrazowy, Przewodnik przyrodniczy [The Welski Landscape Park, Nature guide], Wydawnictwo Urbański, Torun.

Gołdyn R., 2000, Zmiany biologicznych i fizyczno-chemicznych cech jakości wody rzecznej pod wpływem jej piętrzenia we wstępnych, nizinnych zbiornikach zaporowych [Changes in biological and physico-chemical parameters of river water quality as a results of its damming in preliminary lowland reservoirs], Wydawnictwo Naukowe UAM, Poznań.

Gołdyn R. \& Kowalczewska-Madura K., 2005, Chlorophyll a and other water quality variables in lentic and lotic sections of the Cybina river, Oceanological and Hydrobiological Studies 34 (1): 87 - 98.

Granlund K., Räike A., Ekholm P., Rankinen K. \& Rekolainen S., 2005, Assessment of water protection targets for agricultural nutrient loading in Finland, J. Hydrol, 304: 251-260.

Hatfield J. L. \& Follett R. F., 2008, Nitrogen in the environment, Sources, problems and management, Second Edition, Academic Press, New York.

Hermanowicz W., Dojlido J., Dożańska W., Koziorowski B. \& Zerbe J., 1999, Fizyczno-chemiczne badanie wody i ścieków [Physicochemical studies on water and sewage], Wydawnictwo Arkady, Warszawa.

Hillbricht-Ilkowska A. \& Kostrzewska-Szlakowska I., 1996, Zmienność stężenia wybranych związków chemicznych oraz retencja fosforu i azotu w układzie rzeczno - jeziornym rzeki Krutyni (Pojezierze Mazurskie) [Variability in the concentration of selected chemical compounds, as well as retention of phosphorus and nitrogen in the fluvio-lacustrine system of the Kruty- nia River (the Masurian Lakeland)], Zeszyty Naukowe Komitetu „Człowiek i Środowisko” 13: 187-210.

Kajak Z., 1998, Hydrobiologia - Limnologia, Ekosystemy wód śródlądowych [Hydrobiology - Limnology, Ecosystems of freshwaters ecology], Wydawnictwo Naukowe PWN, Warszawa.

Kufel L., 1996, Analiza przemian i retencji związków azotu i fosforu w małym układzie rzeczno - jeziornym (zlewnia rzeki Krutyni, pojezierze Mazurskie) [Analysis of transformations and retention of nitrogen and phosphorus compounds in a small fluvio-lacustrine system (the drainage basin of the Krutynia River, the Masurian Lakeland)], Zeszyty Naukowe Komitetu „Człowiek i Środowisko" 13: 225-235.

Lossow K., Gawrońska H., Łopata M. \& Teodorowicz M., 2006, Role of lakes in phosphorus and nitrogen transfer in the river - lake system of the Mrózka and the upper Łyna rivers, Limnological Review 6: 171-178.

Moreau S., Bertru G. \& Buson C., 1998, Seasonal and spatial trends of nitrogen and phosphorus loads to the upper catchment of the river Vilaine (Brittany): relationships with land use, Hydrobiologia 373/374: 247-258.

Nowiński K. \& Lange W., 2004, Influence of local conditions of nutrients migration on the Progress of eutrophication of lakes of headstream catchment of the Radunia, Limnological Review 4: 183-192.

Orlik T. \& Obrośłak R., 2005, Analiza jakości wód w stawie rybnym w zlewni rzeki Giełczwi [Analysis of the water quality in a fish pond in the drainage basin of the Giełczwia River], Acta Agrophysica 5 (3): 705-710.

Pattinson S. N., Garcia-Ruiz R. \& Whitton B. A., 1998, Spatial and seasonal variation in denitrification in the Swale-Ouse system, a river continuum, Sci. Tot. Environ. 210/211: 289-305.

Raczyńska M. \& Machula S., 2006, Oddziaływanie stawów karpiowych na jakość wód rzeki Krąpiel (Pomorze Zachodnie) [Influence of carp ponds on the quality of waters in the Krapiel River (Western Pomerania)], Infra. Eko. Ter. Wiej., PAN 4: 141-149.

Sapek A. 1996, Zagrożenie zanieczyszczenia wód azotem w wyniku działalności rolniczej, [w:] Azotany w ekosystemach rolniczych [Risk of water contamination with nitrogen due to agricultural activity, [in:] Nitrates in agricultural ecosystems] Zeszyty Problemowe Postępów Nauk Rolniczych 440: 309-337.

Zieliński P., 2003, Prawidłowości występowania rozpuszczonych związków węgla organicznego w wodach rzek północno - wschodniej Polski [Regularities in the occurrence of dissolved organic carbon compounds in the waters of rivers in north-eastern Poland], Rozprawa doktorska wykonana w Zakładzie Hydrobiologii Instytutu Biologii UwB, [PhD Thesis completed at the Department of Hydrobiology, the Institute of Biology, University of Białystok], Białystok. 